\title{
Study of the fractional composition of electroerosive powder materials of the tungsten nickel iron alloy obtained in lighting kerosene
}

\author{
E.V. Ageev*, N.M. Horakova, S.V. Pikalov, M.S. Korolev, V.O. Podanov \\ Southwest State University, 305040 Kursk, Russian Federation
}

\begin{abstract}
The article presents the results of experimental research aimed at studying the fractional composition of electroerosive powder materials of the tungsten nickel iron alloy obtained in lighting kerosene. It has been found that more than half of the total number of particles is particles with a size of less than 47.7 microns. It was also noted that particles with a size less than or equal to 29.37 microns in the powder include $20.0 \%$ of the total volume. The conducted research makes it possible to determine the most relevant field of application of the obtained powder materials and will improve the quality of scientific and technical developments in the field of application of electroerosive powder materials.
\end{abstract}

\section{Introduction}

Heavy alloys based on tungsten are widely used in many areas, including defense industry [1-9]. Today, one of the main problems in the use of these alloys is their waste processing and reuse [10-15]. The existing industrial technologies for grinding such alloys are characterized by large-capacity, high energy consumption and environmental problems. Search for new environmentally friendly technologies for processing waste of heavy tungsten alloys, including the tungsten nickel iron alloy is relevant and necessary.

One of the promising and industrially unapplicable methods of grinding any electrically conductive material is the electroerosive method [16-21]. At the present time, there are no scientific and technical developments on the use of particles of the W-Ni-Fe alloy dispersed by electric erosion as a charge for the production of heavy tungsten pseudo alloys and products from them. For these purposes, comprehensive theoretical and experimental research is required. Carrying out the planned measures allow us to solve the problem of processing waste of heavy tungsten alloys, save expensive tungsten and reuse it.

The aim of the research was to study the fractional composition of electroerosive powder materials of the $\mathrm{W}-\mathrm{Ni}-\mathrm{Fe}$ alloy obtained in lighting kerosene.

\footnotetext{
* Corresponding author: ageev_ev@mail.ru
} 


\section{Materials and Methods}

To realize the planned studies, powders were obtained on a patented installation for electroerosive dispersion (Figure 1). Lighting kerosene was used as a working fluid. As shown by the results of earlier studies, the powder obtained by electrodispersing the waste of the W-Ni-Fe alloy in kerosene consists of particles of regular spherical shape and elliptical shape.

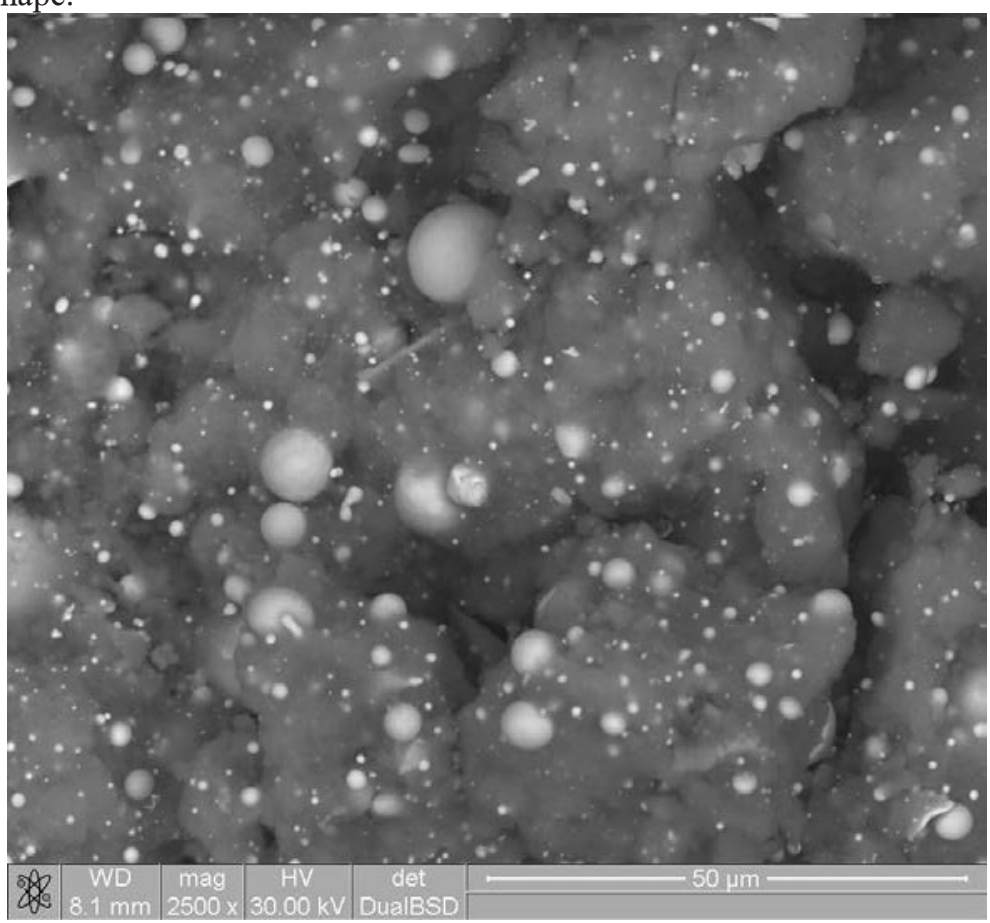

Fig. 1. Electron microscopic image of powder particles obtained in kerosene

The fractional composition of W-Ni-Fe powders was studied using a laser analyzer «Analysette 22 NanoTec» (Figure 2).

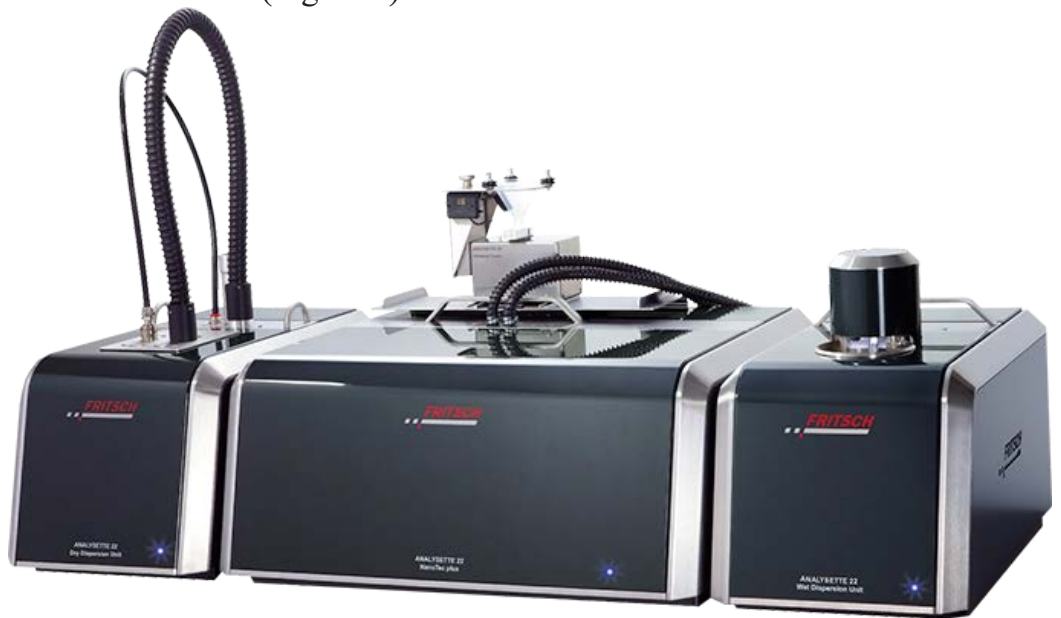

Fig. 2. Laser particle size analyzer «Analysette 22 NanoTec» 
The «Analysette 22 NanoTec» has a measuring range from 0.01 to 2000 microns. Analyzers that determine particle size distribution by means of laser diffraction use the physical principle of electromagnetic wave scattering. The design consists of a laser directed to a detector through a measuring cell. By means of a dispersing device, the particles are fed into the measuring cell and pass through the laser beam. The light scattered in proportion to the particle size is focused onto the detector through a lens. From the distribution of the scattered light, using complex mathematics, the particle size distribution is calculated. The result is volume fractions corresponding to equivalent diameters in laser diffraction. Sample preparation: dispersion of a sample in a liquid. Background measurement - In order to reduce the influence of the measuring liquid, a background measurement is carried out before each measurement. Any contamination from previous measurements is measured and its influence on the current result is eliminated. Measurement of particle size distribution: a sample of the test with a volume of about $1-5 \mathrm{~g}$ was placed in a module for dispersion in liquid (volume of $500 \mathrm{ml}$ ). The measurement started automatically as soon as the absorbance reached the specified value.

Measurement parameters: Measurement type - Fraunhofer method; measurement range - 0.1 [microns] - 265.42 [microns]; resolution - 102 channels $(20 / 383 \mathrm{~mm})$; measurement duration - 100 (scans); regularization is the middle model.

\section{Results}

The results of fractional analysis are shown in the table 1.

Table 1. Fractional composition of W-Ni-Fe powders

\begin{tabular}{|l|l|}
\hline Parameter & Value \\
\hline D10 (10\% of particles), microns & 14.482 \\
\hline D20 (20\% of particles), microns & 29.37 \\
\hline D30 (30\% of particles), microns & 34.993 \\
\hline D40 (40\% of particles), microns & 41.326 \\
\hline D50 (50\% of particles), microns & 47.733 \\
\hline D60 (60\% of particles), microns & 54.229 \\
\hline D70 (70\% of particles), microns & 61.01 \\
\hline D80 (80\% of particles), microns & 69.006 \\
\hline D90 (90\% of particles), microns & 79.913 \\
\hline D95 (95\% of particles), microns & 85.508 \\
\hline d[4.3] Volumetric average diameter, microns & 48.14 \\
\hline$d[3.2]$ Average diameter over surface area, microns & 10.26 \\
\hline$d[3.0]$ Average diameter in relation to volume, microns & 1.79 \\
\hline$d[2.0]$ Average diameter in relation to area, microns & 0.75 \\
\hline$d[1.0]$ Average diameter in relation to length, microns & 0.59 \\
\hline
\end{tabular}

As a result of the exploration of the fractional composition of electroerosive powders obtained from the waste of the W-Ni-Fe alloy in kerosene, it was found that D50 (50\% of particles) -47.733 microns, that is, particles with a size less than or equal to 47.733 microns in the powder contains $50.0 \%$ of the total volume. 


\section{Conclusion}

Based on the experimental studies carried out to study the fractional composition of electroerosive powder materials of the tungsten nickel iron alloy obtained in lighting kerosene, we can conclude that more than half of the total number of particles is particles with a size of less than 47.7 microns. It was also noted that particles with a size less than or equal to 29.37 microns in the powder contain $20.0 \%$ of the total volume. The conducted research makes it possible to determine the most relevant field of application of the obtained powder materials and will improve the quality of scientific and technical developments in the field of application of electroerosive powder materials.

This work was supported by a grant from the President of the Russian Federation (NSh-2564.2020.8).

\section{References}

1. K. Maruyama, T. Nonaka, H.Y. Kim, Effects of $\alpha 2$ spacing on creep deformation characteristics of hard oriented pst crystals of tial alloy, Intermetallics, 2005, vol. 13, No. 10, pp. 1116-1121.

2. Oskolkova T.N., Budovskikh E.A., Electric explosion alloying of the surface of hard alloy vkloks with titanium and silicon carbide, Metal. Sci. Heat Treat, v. 55, pp. 96-99 (2013)

3. Karlsson J., Snis A., Engqvist H., Lausmaa J., Characterization and comparison of materials produced by Electron Beam Melting (EBM) of two different Ti-6Al-4V powder fractions, Journal of Materials Processing Technology, v. 213, pp. 2109-2118 (2013)

4. Gu D.D., Meiners W., Wissenbach K., Poprawe R., Laser additive manufacturing of metallic components: materials, processes and mechanisms, International Materials Reviews, v. 57, pp. 133-164 (2012)

5. N. Radek, Determining the operational properties of steel beaters after electrospark deposition, Maintenance and Reliability, v. 4, pp. 10-16 (2009)

6. A.V. Ribalko, O. Sahin, The use of bipolar current pulses in electro spark alloying of metal surfaces, Surface \& Coatings Technology, v. 168, pp. 129-135 (2003)

7. Z. Chen, Y. Zhou, Surface modification of resistance welding electrode by electrospark deposited composite coatings: Part I. Coating characterization., Surface \& Coatings Technology, v. 201, pp. 1503-1510 (2006)

8. I.V. Galinov, R.B. Luban, Mass transfer trends during electrospark alloying, Surface \& Coatings Technology. v. 79, pp. 9-18 (1996)

9. Azarova E.V., Levashov E.A., Ralchenko V.G., Creation of strong adhesive diamond coatings on hard alloy by electric-spark alloying, Translated from Metallurg. v. 8, pp. 50-55 (2010)

10. A.A. Lipatov, Reactive diffusion in cutting high-alloy steel by means of a hard-alloy tool, Russian Engineering Research, 2013, vol. 33, No. 3, pp. 144-149.

11. A.M. Adaskin, A.A. Vereshchaka, A.S. Vereshchaka, Study of wear mechanism of hard-alloy tools during machining of refractory alloys, Journal of Friction and Wear, 2013, vol. 34, No. 3, pp. 208-213.

12. V.L. Bibik, Forecasting of hard-alloyed cutting tool resistance based on thermal diffusivity, Materials Science Forum, 2013, vol. 762, pp. 777-781.

13. E.V. Azarova, E.A. Levashov, V.G. Ralchenko, A.P. Bolshakov, E.E. Ashkinazi, Creation of strong adhesive diamond coatings on hard alloy by electric-spark alloying, Metallurgist, 2010, vol. 54, № 7-8, pp. 523-529. 
14. Z. Qiao, X. Ma, W. Zhao, H. Tang, B. Zhao, Nanostructured novel cemented hard alloy obtained by mechanical alloying and hot-pressing sintering and its applications, Journal of Alloys and Compounds. 2008. vol. 462. No. 1-2. pp. 416-420.

15. R.A. Latypov, E.V. Ageeva, G.R. Latypova, X-ray microanalysis of powders, obtained by electroerosion dispersion of the alloy W-Ni-Fe, MATEC Web of Conferences 298, 00125 (2019)

16. E.V. Ageev, Hardening technologies and coatings, (2011), 6, 8-14.

17. R.A. Latypov, G.R. Latypova, E.V. Ageev, P.I. Burak, International Scientific Journal, (2013), 5, 80-86.

18. E.V. Ageev, Technology of metals. - (2012), 9, 36-45.

19. Ageev E.V. Obtaining powders from solid alloy waste by the method of electroerosive dispersion / E.V. Ageev // Electrometallurgy. - (2011), 10, 24-27.

20. E.V. Ageev Patent 2449859, Russian Federation, C2, B22F9 / 14. Installation for producing nanodispersed powders from conductive materials, applicant and patent holder Southwestern State University. - No. 2010104316/02; application 02/08/2010; publ. 05/10/2012. - 4 p.

21. E.V. Ageev, E.V. Ageeva // Bulletin of mechanical engineering. - (2013) 11. 51-57 